\title{
5
}

\section{The German phoenix: Berlin 1863}

B erlin underwent a period of prodigious growth in the mid-nineteenth century. Between 1850 and 1870 its population doubled from approximately 400,000 to 800,000 , making it the largest city in German-speaking Europe, larger even than Vienna. In just a few decades the city had shed its provincial image and was able to compete with metropolises like London and Paris on the strength of its economic, cultural and scientific credentials. In 1871 Berlin would become the proud capital city of the new German Empire.

Berlin's growth mirrored the general expansion of Prussia. The political development of the German states had accelerated since the Italian wars of 1859-1860. Central Europe would not accept the borders of 1815 for much longer. The formation of a unified German state was inevitable, but what kind of Germany would it be? A Grossdeutschland solution, integrating Austria and Prussia in a single large state, seemed increasingly less likely, while the Kleindeutschland solution had begun to resemble a 'Greater Prussia' arrangement. Prussia appeared to be fully capable of orchestrating such an arrangement flawlessly under Bismarck's leadership.

German statisticians went about their business amid the political turbulence. Statistics was not a significant topic in the debate on Germany's national future. Within the Zollverein (the German Customs Union), statisticians from the German states met regularly (as they had after the close of the Vienna congress in 1857), but they had no influence of any significance on diplomatic relations. The Zentralbureau des Zollvereins, located in Berlin since 1833, barely had a public function. Yet in many respects statistical practice was bound up with the German question, which had a national component ('Deutschland, aber wo liegt es?'), a political component (who should be involved in the conversation and decision making?) and a social component (how could the effects of economic growth be managed?) The corresponding questions for the German statisticians 
were: how do we organise a national statistics, who should be involved, and in what form can statistics contribute to the management of major social change? Though the fifth statistical congress had a strong international orientation, these German issues were an implicit part of the programme.

At first, tensions in German and international relations threatened to jeopardise the continuity of the international statistical congresses. A row over a Franco-German trade agreement was used as a pretext for postponing the congress, which had originally been planned for 1862 . More serious than the trade conflicts, though, was the domestic political crisis of the spring and summer of 1862, which brought Bismarck to power. The crisis arose when the Prussian House of Representatives refused to approve a military spending increase. King Wilhelm I of Prussia and his ministers sought to provoke a confrontation with parliament. The appointment of Bismarck as prime minister may have had the appearance of a compromise at first, but it soon became clear that the 'white revolutionary' was not much enamoured of parliament. He saw the crisis not as a conflict between liberals, conservatives and other political movements, but rather a battle between the monarchical and parliamentary forms of government. The latter had to be vanquished, whatever the cost. ${ }^{1}$ Wilhelm agreed with Bismarck's reasoning entirely, and both remained loyal to the principle of the strong state throughout their lives.

A strong state was certainly not detrimental to statistics, as Chapters 2 and 3 on France and Austria show. However, it would be wrong to view German government statistics as merely a lifeless appendage of an authoritarian state power. Statistics was a refuge for a more liberal Germany, even in Prussian Berlin. There were few conservative aristocrats among the active statisticians, and it was no coincidence that prominent statisticians like Friedrich Wilhelm Schubert, Johannes Fallati and Friedrich Wilhelm von Reden had been members of the Frankfurt Parliament of 1848-1849. The demise of that liberal episode in German history seemed to spell the end of their role, but the ideas of social progress and prudent steering of state intervention based on the results of statistical inquiry lived on in the universities and statistical bureaux of the German states. For a long time there was no visible political scope for implementing these ideas, which overlapped with the ambitions of the Kathedersocialists, but there is no question that Bismarck's social legislation in the period 1883-1891 was rooted in the body of thought promulgated by most German statisticians around the middle of the century.

Once the first Bismarck government was firmly in charge, the objections to planning the congress evaporated. The Prussian foreign minister, count Friedrich A. zu Eulenburg, was well disposed to the cause (believing as he did that he could completely depoliticise statistics) and delegated the organisation of the congress to his officials. As Alexander von Humboldt's home base, Berlin exerted an undeniable attraction on scientists and scholars. Though the congress had been planned for September, the official preparatory commission did not officially convene until June. Yet, if there had ever been a moment in the history of the international statistical congress when it could be elevated to a higher 
plane, then it was 1863, in Berlin. Ernst Engel, the director of the Prussian statistical bureau, was intent on making the Berlin congress a resounding success. The key to it all was the alpha and omega of Engel's thinking: organisation.

\section{Ernst Engel}

Engel personified nineteenth-century statistics, perhaps more than any other statistician discussed in this book. If he could have organised and registered his own birth, he would have. Statistics, he once wrote, 'accompanies a person throughout their entire earthly existence ... and leaves him only after death - once the precise age of the deceased and the cause of death have been established'. ${ }^{2}$ Ernst Engel was born in Dresden in the Kingdom of Saxony in 1821. He studied mining engineering and visited factories in France, Britain and Belgium in 1847. During his trip, he met Adolphe Quetelet, who made an indelible impression on him. Engel would refer to the Belgian statistician frequently in his writings. In 1883 - after his retirement - Engel published a paper on one of his favourite topics, the economic value of the individual, in which he again lavished praise on Quetelet as the founding father of the inductive method. ${ }^{3}$ In a publication dating from 1895, more than two decades after Quetelet's death, Engel introduced a new unit of measure, which he intended to be used as a basis for the statistics of consumptive spending. He called it the 'Quet', hoping that the name of his intellectual father would live on in common parlance, like Watt and Ampère. However, while Engel's name lives on in the law named for him (the proportion of income spent on basic necessities decreases as income increases), it is not associated with the quet, a concept which has completely evaporated.

In 1848 Engel was appointed to an official commission set up to issue recommendations on industrial labour relations. His performance inspired such confidence that he was appointed secretary of the new statistical bureau of Saxony's interior ministry in 1850. The Saxon government intended to take over the organisation and control of statistics from the Statistische Vereinigung für das Königreich Sachsen, which operated partly outside of the government bureaucracy. However, the new statistical bureau had few resources. Apart from Engel there was no permanent staff, no discretionary funds, and it had only limited authority to conduct its own correspondence. It is a testament to Engel's commitment and diligence as an organiser and publicist that the bureau was soon coordinating a host of activities. Engel also edited several statistical periodicals, which were notable for their substantiated and accurate presentation of figures. Everything he undertook demonstrated that he was a specialist who was firmly committed to his work.

Engel remained with the Saxon bureau for eight years, during which time he planted the seeds of his future reputation as the director of the Prussian statistical bureau. What he introduced in Prussia after 1860, he had already tried repeatedly in Saxony. In 1855 he launched a journal entitled Zeitschrift 
des Statistischen Bureaus des Königlich Sächsischen Ministeriums des Innern, producing a large part of the copy himself. He had done most of the writing for the Mittheilungen des Statistischen Bureaus since 1851 and in 1853 he filled an entire statistics annual on Saxony. Engel used the journal to disseminate his views on the function of statistics as well as his statistical data. Public disclosure, Engel wrote in the introduction to the first issue, is the foundation of statistics. It was also the rationale behind his drive to publish. Citizens had a right to information about their country, just as the state had a right to receive accurate data from its citizens. Unfortunately, both parties failed dismally to fulfil their obligations to one another. Farmers, for example, were reluctant to give an accurate count of their livestock for fear of incurring tax increases. And the state made hardly any effort at all to prove that there was no direct relationship between statistics and taxation.

This situation distressed Engel. Statistics, in his view, was the foundation of state knowledge and government, and a bridge between the interests of the state and those of its citizens. Statistical data revealed the laws that govern the 'mechanism' of social life. With this imagery he broke with the laissez-faire ideology of his time and evoked the eighteenth-century idea of the state as machine. The essence of the comparison was the increasing complexity of society. The older the machine, the more its cogs interlocked and altered each other's speed and direction. Those at the controls' needed not only knowledge of the parts, but also insight into the laws governing their movement. That 'insight', applied to the state, was statistics. And, according to Engel, that was something fundamentally different than collecting data without system or context. ${ }^{4}$ Data on a country and its people accumulated and presented systematically was the instrument that enabled the government to manage society. With this interpretation, Engel began to transcend the ways of thinking of his eighteenth-century predecessors.

In the journal's first year of publication, Engel alluded to every topic that occupied the attention of the international community of statisticians. He was clearly well versed in the debates. Like so many European statisticians, he feared the decline of morality, and that was undoubtedly the driving force behind his endeavours. Engel thought a great deal about the statistics of crime and punishment, for example. He believed that prison statistics should be structured so as to answer questions about what the best punishments were for reducing recidivism. His interests went beyond contemplating the numbers and how they were presented. He also called for the prison system to be reorganised and patterned after the mining industry: in the same way that ores are processed by different methods depending on their composition and texture, prisoners should be dealt with - individually or in small groups - on the basis of their moral, intellectual and physical characteristics. ${ }^{5}$ Engel was both a statistician and a moralist, and - whenever possible - a reformer, an amalgam not uncommon among his colleagues.

The most important component of statistics - in Saxony as elsewhere - was the census. A new census and livestock count were due to be held at the end of 
1855, the ninth since the introduction of the triennial count in Saxony in 1832. Engel used his journal as a platform to explain the benefits of such surveys. He based his case in part on the work of Achille Guillard, the man who coined the term 'demography', whom he had met at the Paris congress in September 1855. As he had done before, he explained that the statistician was in search of the laws that govern human society, like the astronomer investigates the laws that determine the movements of celestial bodies (he knew his Quetelet!) He also gave an example of what he called a 'natural law': the more densely populated a country is, the richer it is and the better the conditions are for further increasing its wealth. ${ }^{6}$ Apparently, the notion of 'natural law' was elastic.

The objective of the census was 'to paint as complete and faithful a portrait as possible of the cultural condition of the state of Saxony and the Saxon people.? The 'portrait' was to contain the following elements: numbers, physical characteristics (sex, age, physical defects), mental condition (i.e. psychological defects), religious denomination (Engel noted that Jews, like the Slavs, were to be registered as a separate race), social circumstances (marital status, occupation, social class, place of residence). These data could be combined in endless ways, for the benefit of the state as well as private initiatives (e.g. life insurance companies). The economy, according to Engel, is driven by the human compulsion to satisfy one's needs: 'while the reader of these pages drinks a cup of coffee, he has the power, whether he realises it or not, to move people of every country, every tribe and every generation to action'.

Engel also addressed the different ways that a census could be organised, a subject that had also been an item on the agenda of the international congresses. For practical and financial reasons he preferred to disseminate questionnaires among heads of households and manufacturers, who would fill in the forms themselves. To encourage the Saxon citizenry, he expressed his expectation that their cooperation would lead to unparalleled results. Engel energetically assumed command by putting three printing houses to work simultaneously to ensure that the forms were sent out in time. He described in detail how many kilograms of paper were used, how much twine and cardboard was needed to package the forms, how the questionnaires were distributed and how many people were involved. He calculated the cost in Thalers of the material, postage and processing. These details show what a colossal intervention a census was in the mid-nineteenth century. The proverbial German Gründlichkeit reflected in Engel's descriptions is typical of his assiduity, which is both amusing and alarming when you consider what a well-run bureaucracy is capable of:

The preparations for packaging 1,600,000 forms began on Sunday 11 November and were in full swing by the 12th. This was a huge operation, requiring considerable concentration and skill from the bureau staff who were given the task of sorting the lists and forms needed for each of the 4,000 towns and cities in Saxony (as determined in advance) and packing them into separate parcels. Task specialisation and cooperation stimulated the staff to work with greater speed. Trained packers combined the parcels into the prescribed post and railway shipping crates, of which there were 434 in total. 
At any given time two or three, and in some cases five, people would be busy taking the boxes to the post office or the station. The whole packing operation was managed by a special functionary from the bureau. The entire staff worked from eight o'clock in the morning to eight o'clock at night, and longer if necessary. As a result, this major undertaking was completed in just eight days, on 20 November. ${ }^{9}$

This was the statistical Schwung that Engel sought. This reflected a mentality that he would later describe as 'the reckless and unflinching pursuit of truth of a person with order and passion in his blood. ${ }^{10}$

Engel managed to muster just as much enthusiasm for a seemingly unimportant livestock count. In his journal, he tried to demonstrate that knowledge of the livestock count would indirectly benefit farmers (whose opposition to statistical inquiry was well-known), because it would enable the government to adapt its interventions to the actual state of affairs. To Engel, livestock and feed were indicators of the moral standard of a people. He believed that English workers outperformed their German counterparts because they ate more meat. The evidence came from comparing the performance of German workers who had emigrated to England with that of the English who came to Germany to work. The German migrants were held in high esteem for their diligence and achievements; conversely, the English became lethargic as soon as they began working on the other side of the Channel. In Engel's opinion, something had to be done about the price of meat in Germany, which was kept artificially high by the government. ${ }^{11}$

A similar political statement precipitated Engel's downfall in Saxony. He repeatedly called upon the state to intervene in order to combat social injustices. He emphasised that state intervention could be effective only if it were based on extensive statistical research, and that would require prodigious funding. Business owners and farmers complained about his inquisitorial research methods. ${ }^{12}$ Is it any wonder that Engel resigned as director of the Saxon bureau in 1858 a disappointed man? The agency was simply too small to achieve the level of accuracy and effort that he demanded. And the House of Representatives in Dresden was unwilling to help him by increasing his budget. Engel's letter of resignation was bitter. It was offensive to him that in eight years of loyal service he had never been offered a salary rise. He resigned, stating that he preferred to continue his career elsewhere but would remain available for consultation. $^{13}$

Engel knew that he could earn considerably more outside the Saxon civil service. For some time, he had been reflecting on the issue of commercial lending. He was eager to alleviate the uncertainties for small borrowers, which corresponded with the ways in which he wanted to deploy statistics in order to safeguard the morality and standard of living of the middle classes. Bankruptcy was common, especially among small traders, and led to the irreversible sequestration of all the unfortunate person's possessions. Engel wanted to offer a degree of protection against loss of hearth and home, and devised a new type of insurance, the mortgage insurance. In 1858 he established the Sächsische 
Hypothekenversicherungsgesellschaft.

His business venture was short-lived. The Prussian statistical bureau had been adrift since the death of its director, Carl Friedrich Wilhelm Dieterici. His replacement would need to be a specialist with considerable organisational skills. Engel had them in spades and was intent on proving it. On 1 April 1860 he was appointed director. Engel immediately began putting together the Prussian presentation for the fourth international statistical congress in London. (Prussia had been noticeably absent in Vienna three years earlier.) He also informed his new minister of his wish to establish a central statistical commission, modelled on the Belgian commission and based on the recommendations of the Paris congress.

Engel's attempts to install such a commission in Saxony had failed, but in Prussia he got a hearing. A coordinating commission was not a superfluous luxury. There were countless government services in Prussia (including the railways) that issued periodic statistical reports. The list for 1863 was 21 pages long and enumerated over four hundred publications. ${ }^{14}$ The commission's remit would include eliminating nonessential surveys as well as identifying gaps in statistical research. The commission would publicise its views in the Zeitschrift des Königlich-Preussischen Statistischen Bureaus, which Engel - mindful of his experience in Saxony - had rolling off the presses just a few months after his appointment in Berlin. The journal was published on a monthly basis and frequently featured a well-wrought article by Engel himself. He also produced the Preussische Statistik, a series of statistical publications with core figures pertaining to the country and the population, and the Jahrbuch für die amtliche Statistik des preussischen Staates.

In 1862 Engel launched a statistics seminar that was without precedent. It was intended for civil servants and scientists interested in acquiring a theoretical and practical knowledge of statistics. The programme was impressive, and adjustments were made from time to time. Professors Georg Hanssen and Ernst Helwing gave instruction alongside Engel in the early years; both taught political science at the university in Berlin. Engel regarded the seminar as a step towards a German national statistics. The statistical bureaus in the German states took little notice of each other and even competed whenever there were political gains to be won. It often happened, Engel once wrote in a memorandum, that statistics were used improperly 'by unauthorised persons to set off political or economic fireworks in order to produce such sound and light effects as to obscure the truth. ${ }^{15}$

Uniformity and scientific method, which underpinned the curriculum of the statistics seminar, were not his only objectives. He also emphasised the importance to Prussia of fulfilling a pioneering role in German statistics. Engel understood that the government was susceptible to arguments of this nature. The Prussian statistical bureau had administrative and scientific significance, but could also be used politically to advance the pursuit of unity under Prussian leadership. The statistics seminar was a strategic instrument but also an unimpeachable one. 
The first course in the theory and practice of statistics for civil servants began with eight students at the end of 1862 . The theoretical component covered economics, finance and statistics. Engel himself was responsible for the practical component. He organised excursions to large factories, hospitals, prisons and other institutions. He allowed the students to assist in the preparations for the fifth international statistical congress, exposing them to statistical practices in other countries. Engel was the driving force behind the statistics seminar for the remainder of his career in public service. He kept the programme up to date and was always looking for new experts to serve as instructors. Geographer and meteorologist Heinrich Wilhelm Dove and ethnographer Richard Boeckh soon joined the staff. In 1869 economist Adolph Wagner and agriculture historian August Meitzen replaced Helwing and Hanssen. Engel never managed to persuade his superiors to invite the eminent, but liberal, jurists Karl J.A. Mittermaier and Rudolf von Gneist to come to Berlin. Considering his personal interest, it is not surprising that Engel incorporated insurance statistics - or rather statistics concerning areas of insurance cover like health, loss, damage, death etc. - in the programme. Another element, at least as important as content and teaching staff, was the atmosphere that Engel aimed to create. He intended the seminar to provide living proof that statistics was a multidisciplinary affair in which theory and practice went hand in hand. Study trips and, in particular, opportunities for discussion were part of that. Engel wanted the seminar to be open not only to civil servants, but also to graduates and students of political science and the natural sciences, and even for members of occupational groups that had an interest in statistics. ${ }^{16}$ The Prussian government felt that this was a bridge too far, but did not forbid Engel to make his proposals in public.

Men who would go on to become famous thinkers, such as Ludwich Joseph 'Lujo' Brentano and Georg Friedrich Knapp, participated in the seminar. The concept of expert training met with enthusiasm abroad, in Jena and in Vienna, where Karl von Czoernig followed the example of his colleague from Berlin. Engel referred to the newly established economics department at the École Pratique des Hautes Études in Paris, but it is doubtful that the French would have ever admitted to copying the Prussian model. ${ }^{17}$ The programme's attention to topics like land tax, conditions of ownership, prices, credit and insurance suggests that the Verein für Sozialpolitik, of which Engel was a working member, owed a great deal to the statistics seminar. Engel's successor, Blenck, once referred to his preceptor as the father of Kathedersocialism..$^{18}$ In fact, there was not much difference between the mission of the Verein and that of the Berlin-based seminar.

Engel had an ambivalent relationship with the Prussian state. Born in Saxony, he was an outsider. He was not schooled in Prussian-style bureaucracy and, in some respects, he was a self-made man. Like many high-ranking civil servants, he had had a brief career in parliament. Between 1867 and 1870 he served as a member of the Prussian Landtag, a dubious honour that left him, and other Prussian officials, with little room to manoeuvre politically. Ministers could dismiss any civil servant at will whose past voting record displeased them. On 
the other hand, it bears remembering that in the 1860s and 1870s there were opportunities in the Prussian state apparatus for men like Engel, who positioned themselves in Prussia, Germany and Europe as advocates of a new, progressive social science and had their sights set on an active state with a practical bureaucratic machinery.

\section{Statistics in Germany: the case of Baden}

Prussia’s power, Berlin's appeal and Engel's authority, though impressive, should not distract us from what was happening in other parts of Germany, where statistics was also flourishing. Most German states had active statistics agencies and they had sent representatives to the congress since 1853. Friedrich von Hermann of Munich, Georg Varrentrapp of Frankfurt, Bruno Hildebrand of Jena, Johann Eduard Wappäus of Göttingen and other prominent scholars came to the congress in Berlin, highlighting Germany's unrivalled position in statistics and related sciences. Since the Napoleonic period, statistics had thrived in Bavaria and the Rhine states. Statistics and state-building went hand in hand, gradually facilitating the periodic publication of national statistics tables about population, agricultural yields and livestock numbers. The liberal 'organisational' politics of the 1830s and the formation of the Zollverein in 1834 accelerated the institutionalisation of statistics in south-west Germany.

The consolidation of the Grand Duchy of Baden, a new medium-sized state in the Rhine Confederation and later in the German Confederation, offered great opportunities for the development of official statistics. In 1835 Wilhelm Ludwig Volz of Rastatt near Karlsruhe, a professor and high government official in Baden, toured Austria, Bohemia, Bavaria, Saxony and Prussia to study how statistical practice was organised. Volz noticed that there was little similarity and that there seemed to be no model for statistics on hand in Baden. There was too little interest to get a private statistical society off the ground and the government considered a full-fledged central statistical bureau too much of a good thing. Volz hoped it would be possible to set up a statistical department at the Ministry of Finance. ${ }^{19}$

Volz's report lay in a desk drawer until 1836 when it was appended to a request from the interior minister Ludwig Georg von Winter to the king. Von Winter wanted to establish a statistical commission, but noted in his request that there was no foreign organisation model that could serve as an example. The aim of the commission, whose membership would comprise experts from science and government, would be to coordinate the collection and processing of statistical data. If the commission functioned well, then further plans could be made for setting up a statistics organisation in Baden. ${ }^{20}$

Von Winter's initiative to improve statistics in Baden was not an immediate success. In 1847 a small budget was set aside to fund a commission, but nothing came of it due to the revolutionary events of the next year. After 1850 a statistical bureau was set up at the interior ministry and transferred to the 
new trade ministry in 1860 . In 1855 the interior ministry began publishing the Beiträge zur Statistik der inneren Verwaltung des Großherzogthums Baden. As a middling-sized state, Baden looked 'abroad' for models of organisation for government statistics, though most were found to be unsuitable. Meanwhile, the finance and interior ministries eagerly amassed statistical publications issued in other German states and France and Belgium.

The Verein für deutsche Statistik, founded by Freiherr von Reden in 1846, had some support in Baden. Von Reden wanted to expand the Zollverein's limited statistical activity and was in search of new avenues. Otto Hübner was working on something similar. In the early 1850 s he wanted to set up a private international statistical bureau and was keen to receive copies of all the official statistical publications he could get his hands on. The government of Baden was inclined to assist by providing printed statistics. Hübner's 'statistical bureau' was in fact a business, which he ran with his brother Heinrich. Their activities included publishing the Jahrbuch für Volkswirtschaft und Statistik, which they launched in 1852. This journal would lead to the periodic publication of global statistical tables, translated into several languages. ${ }^{21}$

If the revolution of 1848-1849 had succeeded, Von Reden's ideas would, no doubt, have gained momentum. At the end of 1848, the Frankfurt Parliament decided to conduct a national census and set up a national bureau for statistics. The government of Baden was favourably disposed towards these initiatives, which were coordinated by an experienced statistician, Johannes Fallati. However, before the project could be launched, the members of the Frankfurt Parliament - including Von Reden - were sent home. ${ }^{22}$

Baden was one of the states that took some interest in the resolutions adopted by the international statistical congress. The Grand Duchy had sent illustrious professors - Robert von Mohl, Karl Mittermaier and Karl Heinrich Rau - to the first congress in Brussels. The Baden government was closely involved in the initiatives introduced at the congresses in Vienna in 1857 and Berlin in 1863 with respect to a common system of statistics in Germany. ${ }^{23}$ The German representatives at the Berlin congress adopted a resolution founding an association that would initially be coordinated by the Hessian government. In 1868 the Hessian representative, August Karl Fabricius, drafted a report enumerating the shortcomings of German statistics. A commission was subsequently set up to improve and expand statistical inquiry in the Zollverein. The commission's recommendations ultimately led to the Kaiserliches Statistisches Amt in 1872, after German unification.

\section{The Prussian preparatory commission}

Engel's plan for international statistics was similar to his programme for Prussian-German statistics. He even envisaged the two converging. To him, it was obvious that the congresses 'assumed the character of the host country.' ${ }^{24}$ This 'national colouring' was in his eyes a logical consequence of the congress 
moving from capital to capital. Yet, he also believed that there was an element of weakness in the situation. A succession of congresses had failed to generate an organisational tradition or a structure, let alone institutional continuity. Engel wanted to force a breakthrough in Berlin: 'The fundamental and most important subject that the congress needs to address during this sitting is its own organisation. ${ }^{25}$

Before Engel could give that ambition substance, he had to make two things clear to the Prussian government and bureaucracy: that the congress should be held (at the appointed time) and that it should address organisational issues. The central statistical commission that Engel created soon after his appointment as director of the Prussian bureau had already launched preparatory consultations in 1862. The main topics were quickly selected: the organisation of the congress, land ownership, prices and wages, railway transport, the comparative health of civilians and soldiers, insurance, the role of statistics in mutual assistance and charity, and the standardisation of coinage, weights and measures. Some subjects had already been addressed at previous congresses, while others were new and reflected Engel's preferences.

The central statistical commission did not organise the congress itself. Instead the task was delegated to a preparatory commission of civil servants, scientists, physicians and entrepreneurs. A key priority at the first session in June 1863 was to make it clear that the congress was not political. Ironically, this vain attempt only served to emphasise the unavoidable political aspects of the congress. The discussion about the participation of experts such as Otto Michaelis, Hermann Schulze-Delitsch, Rudolf Virchow and Rudolf von Gneist in the preparatory commission is a case in point. Their involvement was not without controversy. All four represented progressive views which were consistently pushed to the margins in Bismarck's Prussia. Michaelis, an economist, was closely affiliated with the Fortschrittspartei. Schulze-Delitsch was an outspoken proponent of cooperatives as a solution to poverty, sickness, disability, unemployment and other aspects of the social question. Increasing the power of workers relative to capital was not a goal that appealed to the Prussian state. Moreover, Schulze-Delitsch was part of the democratic camp of the Prussian Chamber, which had clashed with the Junker government a year earlier. Virchow, a prominent sanitary reformer, regarded medicine as a social science and was a declared opponent of Bismarck, a position that made him suspect in the eyes of the Prussian aristocracy. Gneist, an expert on constitutional law, was equally unpopular with the Prussian establishment and usually sided with the progressive liberals on political issues.

With the support of interior minister Eulenburg who, though intolerant of political reform, permitted administrative reform, Engel kept the controversy over the composition of the preparatory commission from escalating and managed to seat a few critical experts. They made an important contribution to the draft issue statements that were prepared by the subcommittees.

One of the subcommittees dealt with 'organisational issues'. Richard Boeckh, a census expert and statistical bureau official, Salomon Neumann, a physician, 
Rudolf von Gneist and, of course, Engel himself were active members of this subcommittee. Engel had drafted an official constitution and byelaws for the international statistical congress, after the example of the German Juristentag and the British National Association for the Promotion of Social Science. He included a permanent representation, initially seated in Brussels and chaired by Quetelet. The congress membership would henceforth be comprised of individuals and collective bodies (municipalities, associations and other organisations). This new structure would transform what had been a periodic gathering into an international organisation. German, English and French would be the official languages. Decisions of the congress, taken by simple majority voting, would be non-binding. Apart from the congress proceedings there would be a regular newsletter, and an international statistical archive and a library would be established. The subcommittee approved Engel's constitution and byelaws, with no apparent concern for their viability.

Engel's intention was to transform the international statistical congress from a think tank into a genuine board of inquiry, capable of investigating 'matters of great international importance. ${ }^{26} \mathrm{He}$ wisely offered no opinion on what those matters were. These ambitions were consistent with the zeal for reform he had shown since his time at the statistical bureau in Saxony. He probably did not anticipate (or simply ignored the possibility) that his scheme would encounter serious resistance in the international statistics community.

The subcommittee also deliberated about the organisation of national government statistics. The previous congresses had urged participating countries to install central statistical committees. Gneist supported this recommendation wholeheartedly, and stressed that a central coordinating body was needed to offset the fragmentation caused by the unavoidable division of tasks within the modern state apparatus. The membership of the central statistical commissions would comprise scientists and representatives of all government bodies that utilised statistics. Furthermore, the commission was to have an advisory function, but also the power to make binding decisions. Acquiring unanimous support for this proposal would not be easy.

The third difficult issue that the subcommittee had to deal with was the census. Neumann, with Engel's support, presented the report. The Berlin census of 1861 was the starting point for several proposals on counting methods. The system involving census agents that had been accepted back in 1853 was rejected because it was too expensive. A more important objection, however, was the implication that the state did not trust the people to provide reliable information. Why were census agents needed if not to verify the data furnished by the heads of households? Neumann and Engel asked rhetorically: 'Should the census be a necessary but feared operation, conducted by strangers, or should it be a great act of national importance, performed by the people themselves, sensibly, willingly and with a sense of patriotic duty? ${ }^{27}$

The city of Berlin carried out experiments in which citizens filled in the census forms themselves and were responsible for organising the counting work. The idea was that the census should become an act of 'self-government'. The spirit of 
Gneist, a great advocate of British forms of self-government, is clearly recognisable in this approach. ${ }^{28}$ Free citizens' census committees would be set up, and membership would be an honorary office. The committees would be at liberty to ask questions of local interest in addition to the compulsory questions. It was suggested that a provision be added to the census law to prevent improper use of individual answers. Could this optimism hold its own against the realism of the representatives of states in which the public mood was unreliable, such as the newly unified Italian state or Russia, or against the anticipated scepticism of the French?

Notably, the subcommittee did not endorse Engel's article entitled 'Where do the boundaries of active citizen cooperation lie in the counting and description of the population?' Engel wondered whether a self-administered census system could work if periods between censuses were long and, as a consequence, experience was lost. Because of this problem active cooperation could only really be expected to flourish if there were statistics associations at various levels. Engel therefore called for local, regional and national associations to be established in all the countries affiliated with the congress. The organisers must have sensed that this proposal had no chance of success.

Of all the major themes that would be addressed at the congress, the most innovative theme was the role of statistics in mutual assistance ('sociale Selbsthilfe') and insurance. Engel knew better than anyone that nineteenthcentury society was a risk society where everyone - not just the poorest of the poor - faced many more hazards than we can imagine. Economic growth had brought greater certainty and stability into the lives of the middle classes and skilled workers, but the remaining uncertainties were all the greater by comparison. Insurance and mutual assistance funds were safety nets for those who had the means. In 1855 the conferees in Paris had discussed different forms of insurance, but the Germans felt that insurance companies could do a great deal to improve the statistical methods underlying their business. Furthermore, the forms designed in Paris had scarcely been used and the statistical inquiry on this issue had yet to begin. Germany had a highly diverse system of healthcare and insurance institutions. In Prussia alone there were a few thousand worker assistance funds operating in the market. Engel himself owned an interest in a Saxon mortgage insurance company and Otto Hübner, who played an active role in the preparatory subcommittee, was director of a Prussian mortgage insurance company.

Engel presented an elaborate two-part report to the subcommittee. In the first part, he explained in detail what mutual assistance was. Mutual assistance funds had sprung up quickly in the wake of the industrial revolution and the emerging 'social question'. Engel believed that the greatest disadvantage of industrialisation was the mass of dependent lives it created: the proletariat 'living hand to mouth, with no prospect of expanding their capital." ${ }^{29}$ The less capacity a working man had to accumulate capital (he added ominously) the more dangerous he was to the state. Mutual assistance was the only solution and one which had great political significance. Engel defined mutual assistance 
as a financial reserve in case a household's main income decreased drastically or disappeared altogether. A loss of income had many potential causes, both macroeconomic and moral. 'Social insurance' was only possible if the dynamics of the effects of all those potential causes could be established mathematically.

The fact that many workers' funds did not operate on a mathematical basis was not only socially deplorable, it was also politically unacceptable. Statistics had a multifarious function: studying the fluctuations between good and bad times in industry, monitoring the relationship between wages and prices, measuring the influence of industries on health and mapping the connections between incapacity for work and age. Then it was necessary to calculate statistically how much money had to be deposited in the funds in order to meet every need without the fund going bankrupt.

Mutual assistance was, in Engel's view, a step towards economic autonomy and independence, the common endeavour of most people living in the nineteenth century. The only way to achieve that goal, apart from adopting the dreaded solution preferred by socialists and communists (transferring the means of production to the workers), was through credit. Mutual assistance was primarily a credit facility. Engel was most likely thinking of the cooperative savings banks so warmly favoured by Schulze-Delitsch. In this regard, too, statistics could provide scientific grounding. It was time 'to develop a system that conceptualised the different aspects of the social problem as a cohesive whole and subjected them to statistical wisdom. ${ }^{30}$ It was particularly clear that good statistics opened the door to solutions for a variety of social and political problems. The scope and gravity of the problems depended strongly on the observer's perspective. Engel chose to reduce the social problem to a collection of needs that could be alleviated by mutual assistance funds.

Engel's narrative on the insurance business pointed in the same direction. Here, too, the goal was to facilitate protection against the risks inherent in modern society, and particularly the risks run by manufacturers, entrepreneurs and tradespeople. The first order of business would be to classify each insurance company, a task that statisticians were happy to assume. Then the spectrum of insured risks could be submitted to a logical analysis. As a result, insurance companies could put their operations on a more rational footing and statistics would have to be accepted as a fundamental science.

Engel had raised the ante too high. The subcommittee, whose membership was mainly comprised of civil servants and representatives of insurance companies, had little regard for his statistical aspirations. The members were interested in an accurate overview of the mutual assistance funds, membership numbers and assets, but they were not too keen on statisticians trying to analyse the background of social inequality and poverty. The subcommittee was more magnanimous when it came to the insurance companies. A majority considered it a duty to use statistics to keep both the public and the insurance companies informed. For the rest, they were interested in the differences among the German states in the laws governing the insurance business and the practical environments in which insurance companies operated. 
Mutual assistance and insurance had become very popular in Germany and, for political reasons, was of particular interest to the liberal elite. This was the primary reason why these themes were on the agenda. The international dimension was, for many, a secondary consideration. German interests were elevated above others in the preliminary talks concerning all the main themes. The growing threat of wage-price gaps, changes in land ownership, the increase in railway goods transport and the health of the population were subjects that flowed directly from the socio-economic advances in Germany. Each one could be translated into a political reform issue, making consensus all the more difficult.

The way many subjects were treated implied a typically bourgeois view of society. Paternalism, genteel forms of engagement and philanthropic capitalism were the leitmotifs of the day. For example, deliberations on accumulating data on children's health led to the idea of conducting a statistical inquiry of schools. That idea was related to a widely held desire to improve, not just analyse, children's health. Physical education offered possibilities. Gymnastics clubs, which were thriving in Germany, could play an important role, not only by stimulating participation in gymnastics as a physical activity, but also by conducting statistical studies of exercise. ${ }^{31}$ Efforts to educate the public, sport, associations and statistics were all components of a broader goal of shaping society, a bourgeois civilising offensive, German-style. Giving an important role to gymnastics clubs in a civilising offensive made the project ill-suited to internationalisation, despite the high expectations of the organisers.

There was great risk in presenting foreign experts with a draft programme laden with such high aspirations. Furthermore, the Prussian government's relentless repressive conduct was provoking resistance among the progressive members of the preparatory commission. Virchow, Neumann and SchulzeDelitsch dropped out after interior minister Eulenburg showed he was serious about ratcheting up censorship of the press.

\section{Statisticians amongst themselves}

The congress sessions were held in the Herrenhaus, the Prussian senate building, at Leipzigerstraße 3. An information office and a post and telegraph office were set up especially for the occasion. Police lieutenant Seyfried was the local civil servant in charge and was introduced to all the conferees. Order was the first priority. There was also a recreation programme. Statistical works, maps and tables were on display in the reading rooms. The participants enjoyed free access to all royal museums and the prison in Moabit, the Charité and Bethanien hospitals and several factories and printing offices. On Monday afternoon, King Wilhelm I held an audience at the palace. Visitors were expected to appear in 'Civil-Gesellschaftsanzug', with insignia. Later there was a musical performance by a military band. On Tuesday evening, the participants attended the royal opera. On Thursday evening, there was a banquet at the Krollsches 
Etablissement in the Tiergarten. Wilhelm arranged for an excursion to the royal gardens and palaces in Potsdam on the last Saturday. The Prussians were proud of their heritage and eager to show it.

The preliminary sessions were a new feature introduced at the Berlin congress. Attendance was restricted to representatives of official statistics organisations. The sessions were held in the senate building and minutes were taken, but Engel wanted to do business without being bound by ceremony and royal ritual. Officially, the invitations to the preliminary sessions came from Quetelet, whom Europe's statisticians still considered to be the first among equals. It is questionable to what extent he was able to live up to this epithet. $\mathrm{He}$ had not yet fully recovered from the stroke he had suffered a few years earlier. Engel shielded him. In a report to his minister, in which he commented on the conferment of honours to foreign delegates, Engel said of Quetelet that he was but a shadow of his former greatness. ${ }^{32}$ Nevertheless the Belgian repeated what he had said about a joint statistical project three years earlier in London. With the support of statisticians from several countries he had made progress and was able to present several tables, which were the earliest beginnings of an official European statistics.

Engel's main priority was to discuss the establishment of a permanent commission. This was, in fact, a subject that was normally on the congress agenda, but he wanted to reach agreement with the official representatives in advance. That would prove difficult. Quetelet was in favour of it, but Engel found a staunch opponent in the Austrian representative, Adolf Ficker, who was safeguarding Habsburg interests in Czoernig's absence. Ficker believed that a permanent commission would spell the end of the congress as a forum for government statisticians. A scientific commission, which is what he believed the permanent representation to be, would never have such easy access to government statistics. William Farr supported his position. In Britain, countless societies and institutes organised scientific conferences, but they were all entirely detached from government. What made the international statistical congress special, in his view, was the direct link it generated between initiatives from below and coordination by the state. Legoyt was satisfied with the way the congress was organised and feared that governments would withdraw if it became institutionalised. Engel and the other conferees had little choice but to turn over the matter to a committee, which would present its recommendations at a later date. It was decided that the range of opinion would be best represented by nominating Engel, Ficker, Farr, Legoyt, Visschers, Schubert and Berg to the committee.

Tensions mounted further during the second sitting of the preliminary meeting. Once again the discussion got bogged down in a dispute over language, an issue that had never been resolved. Most Germans spoke their mother tongue and, though there were interpreters present and some speakers gave a summary in French, this ruffled some feathers. On top of that, there was a long list of topics on which agreement needed to be reached. For the first time, an inventory had been made of all the themes and decisions discussed at previous 
congresses. It was convenient, useful and a step forward organisationally, but at the same time a source of consternation. Engel wanted all the conferees to go through the list and explain to what extent their governments had implemented the agreements. This was a distressing question and touched a raw nerve.

The discussion on this matter was chaotic, perhaps in part because Engel had given Legoyt the chairman's gavel. Some participants were loathe to 'wash their dirty linen' in public. Others were more inclined to report on the state of statistical research in their countries (and provide an unofficial assessment of progress towards compliance with congress decisions and recommendations). A third group called for a quantitative survey. Having to rely on simultaneous translation made things all the more difficult. Compromise was impossible. The second preparatory sitting was a low point in the history of the congress. The participants went their separate ways and would not reconvene until the official opening. Would Engel be able to turn the tide?

\section{The workable compromise: deferral}

The official opening session was held on Sunday 6 September. Some 400 people attended; a quarter of them were foreign, i.e. not Prussian. Interior minister Eulenburg delegated the daily management to Engel. Engel was an animated chairman. Gesticulating excitedly, he switched easily from German to French. Statistician and economist Georg Friedrich Knapp recalled how, during the opening, General Albrecht von Roon observed the proceedings from the diplomatic box with visible scorn and impatience. ${ }^{33}$ Present in an official capacity, Roon was the man whom Bismarck had put forward as a candidate for chancellor a year earlier. Bismarck had as little appreciation for oration and majority decisions as his protégé.

Engel was more inclined towards open exchange and apologised for the unsavoury commotion during the preparation. He explained the programme and the procedures again. The conferees were assigned to sections, which would begin on Tuesday. Monday was reserved for Eulenburg's opening speech and a word of welcome from King Wilhelm at the royal palace. The words of the minister and the king were perfunctory and could not compare with the speech Prince Albert had delivered in London three years earlier. Albert's recent death was openly mourned at the Berlin congress. Ackersdijck, who had played an active role as a Dutch representative in 1860, had also passed away. Remarkably, it was not the official Dutch delegate, Von Baumhauer, but Auguste Visschers, a Belgian, who gave a brief eulogy in Berlin.

The sessions and plenaries began on Tuesday and ended on Saturday. Foremost on everyone's mind was finding solutions to the organisational issues put forward by Engel. The debate in the section devoted to the topic focused on establishing a permanent commission and the relationship it would have with participating states. There was no international model on which to pattern the commission. Intergovernmental organisations with the authority to make 
binding decisions were still beyond the horizon. The statistics system in the German Zollverein might have served as a model, except that everybody knew its organisation was very weak.

A few of the participants pointed out that the international statistical congress was no ordinary scientific gathering but a conference of official government delegates. Opponents of Engel's proposal argued that without the support of governments, international statistics would be dead. Gneist remarked that the power of Engel's idea was also its weakness. Statistics thrives when ideas, insights and findings flow freely, but without the contribution of the states there would be no progress: 'Some may say that these congresses are of an amphibious nature, to which I would reply that amphibians have a place in nature, too ... This dual nature is a blessing for statistics. ${ }^{34}$ The plenary concurred, and deferred a decision on the reorganisation of the congress to a future meeting. In the meantime, an international committee was set up to examine the issue. The Prussian government was called upon to inquire as to whether the participating states would be willing to distribute their official statistics publications to the major libraries of Europe and the United States.

The discussion about central statistical commissions proceeded in a similar fashion. The Brussels and Paris congresses had adopted resolutions on this matter. Gneist's proposal, which the congress accepted by and large, added little to the decisions already in effect. The point was to emphasise that besides meeting regularly to exchange ideas, the commissions should be given a certain degree of decision-making authority. This is where the proposal touched on a sensitive issue: ministerial responsibility. Gneist realised that the congress would find it difficult to take decisions that entailed a fundamental change in the structure of national governments. Consequently, no specifics were laid down as to how the proposal should be implemented.

The third component of the organisational issue was the census. The session was opened by Pietro Maestri, the representative of the recently unified Italian state. Within a year of unification, the Italian government had managed to organise a census that largely satisfied the requirements set by previous international congresses, giving the congress movement at least one feather in its cap. A united Italian state had been forged and now the population needed to be counted, preferably in accordance with progressive standards. The census was an act of national self-affirmation. What Quetelet and his colleagues had ultimately achieved through a massive commitment of effort and resources fifteen years after Belgian independence (the 1846 census) the Italian government managed to pull off within nine months, in a country many times the size of Belgium, with virtually no infrastructure and where three-quarters of the population was illiterate. Haughty and proud, Maestri described how the census had been carried out. He emphasised that the people had played an important part by, for example, volunteering to participate in local census committees. This seemed to mirror the course of events in Hesse and Prussia. What he failed to say was that more than eighteen months after the census precise interim results were still not available and there was a chance that the counting process 
had been seriously flawed.

Ficker and Von Bouschen, the Austrian and Russian representatives, were forthcoming about their serious practical objections to the method proposed by the preparatory commission. Ficker mentioned the problem of the uneducated, who were barely capable of independent participation; Von Bouschen believed that a number of questions were better suited to an ethnographic study than a census, and could not be answered in a self-administered census. Examples included the question concerning language, which was a political issue in Russia. Other questions, such as those on religion and occupation, would 'not be understood' by the agrarian population. The realism of Ficker and Von Bouschen failed to resonate and the session rejected their amendments of the preparatory commission's proposal.

This did not keep Von Bouschen from airing his opinion on the difference between a census and an ethnographic survey again during the plenary. The congress elected to defer discussion on the matter of a precise population description until a later date. Cesare Correnti, who headed the Italian delegation along with Pietro Maestri, made an interesting contribution. He attempted to position his country's recent experience with census-taking in the context of 'European statistics'. He drew attention to the delicate issue of actual versus legal population (the London congress had decided in favour of counting the actual population). The number of available seats in the municipal councils and certain taxes were based on the legal population count, though in many places the numbers were distorted. Many Alpine villages were abandoned in the winter, while the populations of villages in the Maremma region of Tuscany doubled. Correnti posed the practical question of whether 'nations that had implemented liberal administrative practices before modern-day Italy' had found statistical solutions for this discrepancy. By what methods could the size of the legal population be inferred from a count of the actual population? ${ }^{35}$ This was a question no one could answer. The congress adopted a resolution expressing the urgency of finding a suitable criterion.

Engel concluded optimistically that the discussion on census-taking at the fifth congress had raised new questions that would have to be answered at the next congress. Peace was maintained, but at a price. No new concrete agreements were made.

\section{Mutual assistance and insurance}

The session on mutual assistance and insurance split up into subcommittees, one dealing with mutual assistance funds and five others covering life insurance, fire insurance, transport insurance, livestock insurance and mortgage insurance respectively. Most of the participants by far hailed from German states and many were employed by insurance companies. The private sector's interests were therefore well represented. Considering the many manifestations of mutual assistance funds and the wide range of insurance branches, it is no 
wonder that a great deal of time was spent classifying the organisations in question. Classification was a favourite activity of statisticians, but the question of what other role statistics could play kept coming back.

Gustav Hopf, the official representative of Saxony-Coburg-Gotha, was nominated to report to the plenary meeting on the proposals concerning insurance statistics put forward during the preparatory session. He had served as director of the Gothaer Lebensversicherungsbank since 1835 and had attended the international statistical congresses since 1855 . Hopf began by stating that insurance was a product of the advancing 'civilisation' of the nations and could function as an economic stimulus. In order to meet that goal, the insurance business would have to base its operations on facts. Therein lay the connection with statistics. The statistician's task was to 'register accidents, establish how often and in what circumstances they occurred, determine whether accident prevention was subject to a law and, if so, identify that law. ${ }^{36}$

There were limits, though, to the matters that statistics should address. Hopf was of the opinion that the some of the proposals Engel had included in his preliminary programme were too ambitious. Hopf believed that statisticians should not concern themselves with consumer requirements concerning the financial accountability of insurance companies, nor with the statutory provisions governing insurance, nor with the oversight activities conducted by the state or by an independent agency. Hopf's restrictions reduced the scope of Engel's proposals significantly. What is more, the members of the preparatory session were unable to reach agreement on mortgage insurance, a subject of particular interest to Engel.

Hopf presented two types of resolution in the end. First, he made a few general points about information sharing between statisticians and insurers; second, he submitted questionnaires on the most common forms of insurance. It was unclear, however, whether the non-German states would be able to use the questionnaires. Nevertheless, the congress adopted the resolutions without substantial comment.

International comparability was less of an issue when it came to the statistics of mutual assistance funds. Auguste Visschers took a keen interest in the matter and provided a French translation of the deliberations. Visschers was able to use the subject of assistance funds as a segueway to a theme that he had raised at the Brussels congress in 1853, namely the statistics of workers' budgets and the general living standard of the working class. The issue of mutual assistance funds was closely related to research into the social condition of the working class and the role of the state in improving it. Proponents of mutual assistance believed that the poor would not have to rely on public relief if the funds functioned well. Again, the resolutions could be divided up into two categories: classification of, and further information about, the various funds, and general preferences with regard to data on the dispersion of the funds, their legal status and their connection with poor relief.

The limits of the statistical component of research into mutual assistance funds remained vague, and it was difficult to draw conclusions about the scope 
of the funds' activities which varied from city to city and from country to country. Eugène Rendu, an inspector from the French education ministry, was of the opinion that the congress should encourage members of the assistance funds and affiliated organisations to learn foreign languages. This was consonant with the planned inquiry into a special form of mutual assistance, namely 'the acquisition and enhancement of intellectual capital.' Clearly, the self-help theme was part of the civilisation offensive. The questionnaire pertaining to intellectual development was twice as long as all the questionnaires on the other forms of mutual assistance put together. The statisticians thought it was important to map as accurately as possible the intellectual and moral condition of the lower classes.

Continuing in that vein, Rendu had another brilliant idea. He wanted to see international schools established in a number of countries. While his audience applauded this commendable goal, the proposal was not brought to a vote at the Berlin congress, but an international commission was to be set up to explore the matter further. All in all the congress failed to make any real advancements in the area of mutual assistance funds and insurance and little came of Engel's aspirations.

All that remained was to discuss where the next congress would be held. All the great powers, apart from Russia, had hosted the international statistical congress. On behalf of the Italian government, Correnti proposed Turin, Italy's capital at the time. However, not everyone considered Italy a serious contender. A few German delegates were interested in Berne, but Georg Varrentrapp remarked that 'a place in a remote corner of Europe could never be truly international. ${ }^{37}$ Incidentally, he did not consider Turin to be on the periphery of Europe. He thought that the congresses should always be held in 'Central Europe', i.e. along the line running from Britain, through the Netherlands, to Northern Italy. Farr and Engel favoured St Petersburg, the Russian capital. After all, Russia had put in an appearance at two congresses and as a great power was entitled to host such an important scientific forum. By way of encouragement, the congress had adopted a resolution calling upon the Russian tsar to adopt the Gregorian calendar. As before, the final choice was left up to the hosts, in this case the Prussian organisers. Since the Italians had made a concrete offer, the capital of Italy seemed a logical choice. Only Turin was no longer the capital by the time the next congress was held and the honour fell to Florence.

The Berlin congress evoked contradictory interpretations. On the one hand, the Prussians had in Ernst Engel a great organiser. He was the first to produce a printed list of the decisions taken by previous congresses. He had prepared an extensive programme and had major plans for the future of the congress. Engel was also a good strategist. He managed to persuade the Prussian government to support the congress by stressing national interests; he impressed upon the Prussian bureaucracy the administrative benefits of good statistics; and at the congress was scientific neutrality personified. The conferees did not go home empty-handed: the decisions made by the congress took up over fifty 
pages of the proceedings. As was so often the case, the positive results came from an unexpected quarter. Henri Dunant, Switzerland's official representative, requested and received the attention of foreign governments for the International Committee of the Red Cross, which would hold its first conference in Geneva in October 1863.

Regrettably, the congress's lack of puissance overshadowed the conferees' good intentions. Little remained of Engel's ambitious proposals on organisational matters, the census, self-help and insurance. The time was not ripe for the international standardisation of coinage, weights and measures, a subject that had been on the agenda before. Even efforts to facilitate collaboration among the German statisticians failed to produce results. Serious talks about expanding Zollverein statistics only resumed once German unification was more or less complete. In 1869 Engel attempted to set up a Statistisches Vereinsnetz für die Länder deutscher Zunge, as Von Reden had tried to do over twenty years before. The founding of the Imperial Statistical Service put an end to self-administered statistics in Germany. Engel, too, was forced to accept the dictates of the new state. During the French-German War (1870-1871) he visited Strasbourg and ultimately produced a detailed statistical study of the war. ${ }^{38} \mathrm{He}$ had found yet another way to channel his passion.

Engel was disappointed in the Berlin congress. He found it intolerable that the local authorities in Berlin had done so little for the congress. The Jewish banker Gerson Bleichröder had organised a banquet for the conferees at his own expense, thus saving the organisers from embarrassment. Engel hoped that the conferment of honours on the official representatives, as France and Austria had done, would go some way to making amends. But there can be little doubt that the hopes of Engel and others who dreamt of an international standard for statistics grew dimmer in 1863.

\section{Notes}

1 O. Pflanze, Bismarck and the Development of Germany, I, The Period of Unification, 18151871 (2nd edn, Princeton 1990), p. 177.

2 Cited in I. Hacking, The Taming of Chance (Cambridge 1990, reprint 1998), p. 34.

3 E. Engel, Der Werth des Menschen (Berlin 1883), pp. 1-2.

4 Zeitschrift des Statistischen Bureaus des Königlich Sächsischen Ministeriums des Innern 1 (1855), no. 2, 17.

5 Ibid., no. 6, 90.

6 Ibid., no. 9, 143.

7 Ibid., 150.

$8 \quad$ Ibid., 157.

9 Ibid., 160.

10 The concluding words of E. Engel, System der Demologie (Berlin 1871).

11 Zeitschrift des Statistischen Bureaus des Königlich Sächsischen Ministeriums des Innern 1 (1855), no. 10-11-12, 161-184.

12 Cited in F.-W. Schaer: 'Die Mitwirkung der nationalökonomischen Disziplin bei der Neuorganisation des Preußischen Statistischen Büros im Jahre 1860', Vierteljahrschrift für Sozial- und Wirtschaftsgeschichte 56 (1969), 236. 
13 Sächsisches Hauptstaatsarchiv Dresden, Ministerium des Innern, no. 689, Bestallungsdekrete beim statistischen Büreau, 1850-1874, Bl. 51-52r.

14 I. Hacking, 'Prussian Numbers 1860-1882', in L. Krüger, L.J. Daston and M. Heidelberger (eds), The Probabilistic Revolution, I, Ideas in History (Cambridge, MA and London 1987), p. 380.

15 Report of Ernst Engel (9 June 1861), GStA PK, I. Hauptabteilung, Repositur 77, Ministerium des Innern, Abteilung I, Section 13. Titel 94 (Statistik), No. 113 Statistisches Seminar, Bd. 1 (1862-1870).

16 E. Engel, 'Das statistische Seminar und das Studium der Statistik überhaupt', Zeitschrift des Königlichen Preussischen Statistischen Bureaus 11 (1871), 186.

17 Ibid., 185.

18 B. Földes, 'Ernst Engel', Allgemeines Statistisches Archiv. Organ der Deutschen Statistischen Gesellschaft 11 (1918-1919), 231.

19 Generallandesarchiv Karlsruhe, Abt. 237, Finanz Ministerium, no. 7119, report of Volz, 21 December 1835.

20 Generallandesarchiv Karlsruhe, Abt. 233, Staatsministerium, no. 32766, letter from Winter to the King, 16 June 1836.

21 Generallandesarchiv Karlsruhe, Abt. 233, Staatsministerium, no. 3094, documents related to the statistical bureau of Otto Hübner.

22 Generallandesarchiv Karlsruhe, Abt. 233, Staatsministerium, no. 3094, documents related to the Verein of Von Reden and the Frankfurt Parliament.

23 Generallandesarchiv Karlsruhe, Abt. 233, Staatsministerium, letter from the Ministry of the Interior, 19 December 1857.

24 E. Engel, 'Einleitendes', Die fünfte Sitzungsperiode des internationalen statistischen Congresses in Berlin vom 4. bis 12. September 1863. I, Bericht über die Vorbereitung des Congresses (Berlin 1865), p. 6.

25 Ibid., p. 7.

26 Ibid., p. 11.

27 Ibid., p. 19.

28 In 1863 the second edition of one of Gneist's most influential books appeared: Geschichte und heutige Gestalt der englischen Communalverfassung oder des Selfgovernment (2nd edn, Berlin 1863)

29 Die fünfte Sitzungsperiode, I, p. 57.

30 Ibid., p. 64.

31 Ibid., p. 115.

32 GStA PK, I. Hauptabteilung, Repositur 77, Ministerium des Innern, Abteilung I, Section 13. Titel 94 (Statistik), No. 116, Bd. 1, Engel to the minister of the Interior, 21 September 1863.

33 G.F. Knapp, Grundherrschaft und Rittergut. Vorträge nebst biographischen Beilagen (Leipzig 1897), p. 143.

34 Die fünfte Sitzungsperiode, II, p. 97.

35 Ibid., p. 470.

36 Ibid., p. 508.

37 Ibid., p. 522.

38 E. Engel, 'Beiträge zur Statistik des Krieges von 1870-71', Zeitschrift des Königlichen Preussischen Statistischen Bureaus 12 (1872), 1-320. 